\title{
Assessment of knowledge and practices of healthcare workers towards infection prevention and associated factors in healthcare facilities of West Arsi District, Southeast Ethiopia: a facility-based cross-sectional study
}

\author{
Biniyam Sahiledengle Geberemariyam ${ }^{1 * \dagger}$, Geroma Morka Donka ${ }^{2+}$ and Berhanu Wordofa ${ }^{3}$
}

\begin{abstract}
Background: The prevention of healthcare associated infections is central to the provision of safe, high quality healthcare. Infections acquired in healthcare facilities are a major public health concern, contributing to increased morbidity, mortality, and cost in both developed and developing countries. Although most of these infections can be prevented with relatively inexpensive infection prevention and control measures in many developing countries, in sub-Saharan African healthcare facilities have no effective infection prevention programs. Additionally, there is limited information on healthcare worker infection prevention knowledge and practice in countries such as Ethiopia. The aim of this study was to assess the knowledge and practices of healthcare workers with respect to infection prevention and associated factors in healthcare facilities in southeast Ethiopia.

Methods: A facility-based cross-sectional study design was used to study healthcare workers in the southeast, Ethiopia. Multi-stage sampling was employed to select 680 healthcare workers from 30 randomly selected healthcare facilities. Data was collected using a self-administered structured questionnaire. Descriptive statistics were computed. Multivariable logistic regression was performed to identify factors associated with healthcare workers infection prevention knowledge and practice.

Results: A total of 648 healthcare workers participated in this study, for a response rate of $95.3 \%$. Of these, $53.7 \%$ (95\% Cl: 49.8, 57.4\%) and 36.3\% (95\% Cl: 32.4, 40.1\%) of the respondents were assessed as knowledgeable and reported safe infection prevention practices respectively. The likelihood of self-reporting safe infection prevention practice significantly increased if healthcare workers had received training ( $\mathrm{AOR}=5.31 ; 95 \% \mathrm{Cl}: 2.42,11.63$ ) and had infection prevention guidelines available $(A O R=3.34 ; 95 \% \mathrm{Cl}: 1.65,6.76)$. Healthcare workers were more likely to have infection prevention knowledge if they worked longer ten years or more $(\mathrm{AOR}=3.41 ; 95 \% \mathrm{Cl}: 1.22,9.55)$; worked in facilities with infection prevention committees (AOR $=1.78 ; 95 \% \mathrm{Cl}: 1.01,3.13$ ), had infection prevention guidelines available (AOR $=2.44 ; 95 \% \mathrm{Cl}: 1.45,4.12)$; had training (AOR $=5.02 ; 95 \% \mathrm{Cl}: 1.45,8.59)$.

(Continued on next page)
\end{abstract}

\footnotetext{
* Correspondence: biniyam.sahiledengle@gmail.com

${ }^{\dagger}$ Biniyam Sahiledengle Geberemariyam and Geroma Morka Donka contributed equally to this work.

'Department of Public Health, School of Health Science, Madda Walabu

University Goba Referral Hospital, Bale-Goba, Ethiopia

Full list of author information is available at the end of the article
}

(c) The Author(s). 2018 Open Access This article is distributed under the terms of the Creative Commons Attribution 4.0 International License (http://creativecommons.org/licenses/by/4.0/) which permits unrestricted use, distribution, and reproduction in any medium, provided you give appropriate credit to the original author(s) and the source, provide a link to the Creative Commons license, and indicate if changes were made. The Creative Commons Public Domain Dedication waiver (http://creativecommons.org/publicdomain/zero/1.0/) applies to the data made available in this article, unless otherwise stated. 
(Continued from previous page)

Conclusions: Inadequate infection prevention knowledge and unsafe practices were frequent among study participants, reflecting a potentially common problem at public healthcare facilities in southeast Ethiopia. Healthcare workers have better knowledge and safer practices if they had received infection prevention training and had infection prevention guidelines in their workplace. Interventions should be designed to consider these identified factors.

Keywords: Infection prevention, Knowledge, Practice, Healthcare-associated infection, Ethiopia

\section{Background}

Infection prevention plays a key role in preventing and reducing the rate of healthcare associated infection (HAIs). HAIs, are the most frequent adverse event in healthcare worldwide can occur as a part of an endemic or epidemic situation and affect the quality of care of hundreds of millions of patients every year in both developed and developing countries [1, 2]. According to the Centers for Disease Control and Prevention (CDC), HAIs defined as infections localized or systemic condition resulting from adverse reaction to the presence of infectious agent or its toxins acquired from health care settings that was not incubating or symptomatic at the time of admission to the healthcare facility [3]. These infections are a major public health concern and a threat to patient safety, contributing to increased morbidity, mortality, and cost [2, 4]. Based on the available evidence, the overall impact of HAIs implies prolonged hospital stay, long-term disability, increased resistance of microorganisms to antimicrobials, high costs for patients and their family, and unnecessary deaths [5-7]. In addition, it places a significant massive additional economic burden on the health care system [8].

According to World Health Organization (WHO), of every 100 hospitalized patients, 10 in developing countries and 7 in developed countries will acquire at least one HAI [9]. The CDC also estimates that 2 million patients suffer from HAIs every year and nearly 100,000 of them die in United States (US) [10]. In US and Europe the point prevalence of patients with at least one HAI in acute care hospitals has reached 6\%, prevalence (19.5\%) was highest among patients admitted to intensive care units (ICU) $[11,12]$. By contrast in developing countries, the problem is three times higher when compared to the incidence observed in adult intensive care units in the US [1]. It is also thought that the prevalence is more than $40 \%$ in parts of Asia, Latin America and sub-Saharan Africa [13, 14]. In sub-Saharan Africa lone, the rate of HAIs ranges from 2.5 to $30.9 \%$ with patients undergoing surgery, the most frequently affected [1517]. This high proportion of surgical site infection is also seen in studies conducted in Ethiopia, with the prevalence ranging from 11.4 to $52.1 \%$ [18-21].

The high burden of HAIs in Ethiopia as well as in many developing countries has been reported to be higher because of the large number of patients, the limited number of staff, and insufficient compliance with infection prevention and control measures [22-25]. Strict adherence to infection prevention protocol is critical to avoiding spread of infection among hospitalized patients and fundamental to quality of care [14, 25-27]. Infection prevention programs, including campaigns to improve hand hygiene, are effective in reducing HAIs [28]. Even a small improvement in hand hygiene compliance by $10 \%$, was associated with a $6 \%$ reduction in overall HAIs and $14 \%$ reduction in healthcare-associated Clostridium difficile infection [29]. In support of this, effective implementation of infection prevention practices in healthcare facilities leads to a significant reduction more than $30 \%$ in HAIs [30]. The financial impact of infection prevention practices is also estimated to be $\$ 25.0$ billion to $\$ 31.5$ billion in medical cost savings in US [31, 32].

There is little evidence concerning the burden of unsafe care and infection prevention practice in resource limited settings [19, 33-37]. Although most HAIs can be prevented with relatively inexpensive infection prevention and control measures such as hand washing, studies have shown that healthcare facilities in Africa do not have effective infection control programs [13, 14, 24, 25].

In Ethiopia, different activities have been made relentlessly by Federal Ministry of Health of Ethiopia to scale up infection prevention program and to put together all up-to-date information and practical interventions in the area of infection prevention and patient safety as a healthcare reform initiative [13, 25]. Despite of this efforts, infection prevention activities is low [37-39] and high burden of HAIs in Ethiopia is a great concern [1821]. In addition to this, there is limited national data on infection prevention regardless of the dramatic increase in the development of healthcare facilities. Few studies have been conducted and the majority of them are case studies limited to a few healthcare facilities in close proximity to each other [37-44]. In the study area of southwest Ethiopia, to our knowledge, no studies have 
been undertaken on infection prevention knowledge and practice among healthcare workers. The first step to developing a successful infection control program is to undertake an assessment of existing infection prevention practice [35]. Therefore, this study aimed to assess the knowledge and practice of healthcare workers towards infection prevention and associated factors in healthcare facilities in southeast Ethiopia. The present study will be essential for policy and decision makers in the development of HAIs prevention programs, and strategic plans. The finding also helps healthcare workers to improve the quality of healthcare delivery services and infection prevention activities.

\section{Methods}

\section{Study design, setting and population}

A facility-based cross-sectional study was conducted from April 6 to 10, 2015 in public healthcare facilities in West Arsi District, Southeast Ethiopia. According to the West Arsi District Health Department Biannual Healthcare Workers Profile Report, there are a total of 2175 fulltime healthcare workers working in eighty-one healthcare centers, two primary hospitals and one general hospital. All healthcare workers working in the healthcare facilities who provide care and have direct involvement in patient care were eligible to be included in the study. These workers were physicians, health officers, nurses, midwives, anesthetists, laboratory technicians, laboratory technologists, pharmacists, pharmacy technicians, environmental health officers, and radiographer. Individuals who were on annual and maternity leave during data collection time and those who could not respond to the questions due to illness were excluded from the study.

\section{Sample size determination}

The sample size was determined using the single population proportion formula. It was computed by considering that previous study has demonstrate that $84.2 \%$ of the respondents demonstrated good infection prevention knowledge and $54.2 \%$ demonstrate safe practices towards infection prevention [44]; a 95\% confidence level, and $5 \%$ margin of error. The largest sample size was considered $(n=381)$. A finite population correction formula was considered since the source population is less than 10,000. Accordingly, the required total sample size was 680, after taking a design effect of 2 and 5\% non-response rate.

\section{Sampling procedure}

A multi-stage sampling technique was used to select study participants. First, all public healthcare facilities in West Arsi District were stratified based on their level of service delivery as general hospital, primary hospital and health center [45]. Then, one general hospital, one primary hospital, and 28 health centers were randomly selected using a lottery method. The calculated sample sizes $(n=680)$ were allocated proportional to each selected facilities. Finally, healthcare workers were selected by using a lottery method from the list of healthcare workers obtained from each facility (117 selected from the general hospital, 72 from the district hospitals and 491 from health centers).

\section{Variables and measurements}

The dependent variables studied were knowledge and practice of healthcare workers towards infection prevention. Whereas, the independent variables include sex, profession, educational level, year of service, presence of infection prevention committee, availability of infection prevention guidelines in the working department, training about infection prevention, and availability of water in working department.

Healthcare workers' knowledge regarding infection prevention was measured by ten "yes or no" questions. A scoring system was used in which the respondent's correct and incorrect answers provided for the questions were allocated " 1 " or " 0 " points respectively. Knowledge scores were summed up to give a total knowledge score for each healthcare worker. The total score of knowledge questions ranging from 0 to 10 were classified into two categories of response: knowledgeable (if above the mean) and not knowledgeable (equal to or below the mean) $[37,44]$.

The healthcare workers infection prevention practice was measured by ten items in which responses were answered in a three point Likert scale (always or yes, sometimes, never) options. To analyze the practice, similar procedures were followed a score of 1 was assigned for each acceptable or correct practice and 0 for unacceptable, hence the total score of infection prevention practice ranged from 0 to 10 . Accordingly, healthcare workers infection prevention practice was classified into two categories: safe (if above the mean) and unsafe (equal to or below the mean) [37, 44].

\section{Data collection procedures and quality control}

A pre-tested structured self-administered questionnaire was used to collect data. The data collection tool was developed by reviewing relevant literature $[13,14,25]$ and by adapting the content from related studies [40, 44]. The data collection tool was first prepared in English, translated to Afan Oromo (the local language) then retranslated to English to check for consistency. Data collection was facilitated by five trained nurses and two supervisors. To enhance instrument reliability, the instrument was pre-tested on 34 individuals $(5 \%$ of the 
intended sample size drawn from outside of the study area in nearby healthcare facilities of Bale Zone with similar characteristics to those in the study). In addition, to improve the validity of the questions the tool was checked by two experts in the field of infection prevention; based on their comments corrections were made before data collection.

The data collection tool was a three-part questionnaire. The first part of this questionnaire included the background and demographic features of healthcare workers (age, sex, marital status, profession, educational level, year of service, history of infection prevention training, and the presence of infection prevention guidelines in their department). The second part consists of ten questions concerning knowledge about infection prevention on the following topic: general awareness regarding infection prevention, personal protective equipment (PPE), hand washing, alcohol based hand antiseptic, tuberculosis (TB) infection control measures, medical instrument decontamination, healthcare waste handling, and infections transmitted through needle stick injuries. The third part consisted of ten questions self-reporting infection prevention practices in the areas of PPE utilization, hand hygiene, instrument processing, healthcare waste handling, and safe injections. The data collection process which occurred over a five day period was checked by two supervisors on daily basis. Questionnaires were checked for completeness and consistency. The data collection tool was tested for internal consistency (reliability) using Cronbach's alpha test. The resulting Cronbach's alpha values were 0.812 and 0.751 for the knowledge and practice sections, respectively.

\section{Data processing and analysis}

Data were entered into Epi-Info version 3.5.1 software and exported to SPSS version 21 for analysis. Descriptive statistics were used to present the frequency distribution of important variables. For the purposes of analysis, the dependent variables were dichotomized into binary outcome variable indicating; "infection prevention knowledge" was coded as "knowledgeable $=1$ " and "not knowledgeable $=0$ " and "infection prevention practice" coded as "safe $=1$ " and "unsafe $=0$ ". Initially, bivariate analyses were performed to assess association between the dependent and independent variables and those variables with a $p$-value of $<0.25$ were then entered into multivariable logistic regression to control the effect of confounder's and to estimate the independent predictors of infection prevention knowledge and practice [46]. A regression model was built by stepwise logistic regression procedure. Predicting power of variables in the final fitted model was checked by receiver observed characteristics (ROC) curve. The Hosmer and Lemeshow test was used for overall goodness of fit [47]. Odds ratios with 95\% confidence intervals were used to determine the strength of association between the dependent and independent variables. All tests were two-tailed and $p$-value $<0.05$ was used as a cut-off point for all statistical significant tests.

\section{Results}

Socio-demographic characteristic of healthcare workers

A total of 648 healthcare workers participated in the study, for a response rate of $95.3 \%$.The mean (standard deviation) age of healthcare workers was $28.23( \pm 5.2)$ years. Four hundred forty-six $(68.8 \%)$ of participants were male. The majority of them (61.4\%) were nurses (Table 1).

\section{Knowledge about infection prevention}

In this study, only 348 (53.7\%) [95\%CI: 49.8, 57.4\%] of the respondents found to be knowledgeable about infection prevention (Table 2).

\section{Self-reported infection prevention practice}

In this study, the proportion of healthcare workers who reported safe infection prevention practice was found to be $235(36.3 \%$ ) [95\%CI: 32.4,40.1\%] (Table 3). Four hundred fifty (69.4\%) reported that they frequently wash their hands after patient care, 416(64.2\%) after removing gloves, 412 (63.6\%) before care of wounds, and 364 (56.1\%) before patient care.

\section{Healthcare workers occupational exposure status}

The life-time prevalence of self-reported needle stick injury and blood or body fluid exposure was 210 (32.4\%) [95\% CI: 28.7, 36.1\%] and 253 (39.0\%) [95\% CI: 35.2, 43.1\%] respectively. Among healthcare workers who reported needle stick injury, 131 (62.4\%) were injured once, 52(24.8\%) reported two injuries and $27(12.9 \%)$ were injured three or more times. Healthcare workers received needle stick injuries while securing intravenous catheters $58(27.62 \%)$, during recapping 72(34.29\%) during suturing 110(52.38\%), during the handling of healthcare waste $9(4.29 \%)$ and during blood sample taking 10(4.76\%). Respondents indicated that the disease transmitted by needle stick injury were Human Immunodeficiency virus (HIV) 636(98.1\%), Hepatitis B virus (HBV) 511(78.9\%), Hepatitis C virus (HCV) 302(46.6\%), and Tuberculosis (TB) 7(1.1\%).

\section{Factors associated with knowledge of healthcare workers towards infection prevention}

In the bivariate analysis, sex, profession, service year, presence of infection prevention committee, presence of infection prevention guideline, and ever taking training on infection prevention were factors which were significantly associated with knowledge about infection prevention. However, only profession, service year, presence 
Table 1 Socio-demographic characteristic of healthcare workers in healthcare facilities of West Arsi District, Southeast Ethiopia, April $2015(n=648)$

\begin{tabular}{|c|c|c|c|}
\hline Variables & Category & Number & Percent \\
\hline \multirow[t]{4}{*}{ Age } & $18-29$ & 345 & 53.2 \\
\hline & $30-39$ & 262 & 40.4 \\
\hline & $40-49$ & 36 & 5.6 \\
\hline & $\geq 50$ & 5 & 0.8 \\
\hline \multirow[t]{2}{*}{ Sex } & Male & 446 & 68.8 \\
\hline & Female & 202 & 31.2 \\
\hline \multirow[t]{4}{*}{ Marital status } & Single & 349 & 53.9 \\
\hline & Married & 284 & 43.8 \\
\hline & Divorced & 13 & 2.0 \\
\hline & Widowed & 2 & 0.3 \\
\hline \multirow[t]{5}{*}{ Profession } & Nurse & 398 & 61.4 \\
\hline & Midwife & 104 & 16 \\
\hline & Health Officer & 51 & 7.9 \\
\hline & Physician & 22 & 3.4 \\
\hline & $\begin{array}{l}\text { Laboratory technicians } \\
\text { and others }\end{array}$ & 73 & 11.3 \\
\hline \multirow[t]{3}{*}{ Educational level } & Diploma & 394 & 60.8 \\
\hline & First degree & 242 & 37.3 \\
\hline & $\begin{array}{l}\text { Second degree \& } \\
\text { above }\end{array}$ & 12 & 1.9 \\
\hline \multirow[t]{4}{*}{ Year of service } & $<5$ years & 390 & 60.2 \\
\hline & 5-9 years & 170 & 26.2 \\
\hline & $10-14$ years & 48 & 7.4 \\
\hline & $\geq 15$ years & 40 & 6.2 \\
\hline \multirow{2}{*}{$\begin{array}{l}\text { Ever taken training } \\
\text { on infection prevention }\end{array}$} & Yes & 184 & 28.4 \\
\hline & No & 464 & 71.6 \\
\hline \multirow{2}{*}{$\begin{array}{l}\text { Presence of infection } \\
\text { prevention committee }\end{array}$} & Yes & 430 & 66.4 \\
\hline & No & 218 & 33.6 \\
\hline \multirow{2}{*}{$\begin{array}{l}\text { Availability of infection } \\
\text { prevention guidelines in the } \\
\text { working department }\end{array}$} & Yes & 310 & 47.8 \\
\hline & No & 338 & 52.2 \\
\hline
\end{tabular}

- Pharmacist, pharmacy technicians, anesthetist and environmental health officers

of infection prevention committee, presence of infection prevention guideline, and ever taking training on infection prevention were found to be significantly associated in the multivariable logistic regression model.

Physicians were $85 \%$ less knowledgeable on infection prevention than nurses [AOR (Adjusted Odds Ratio) $=$ 0.15, 95\% CI: 0.05, 0.45]. Those healthcare workers who have served for ten and above years were about 3.41 times more likely knowledgeable about infection prevention than those whose service years are less than five years $(\mathrm{AOR}=3.41,95 \%$ CI: 1.22, 9.55). Those healthcare workers in facilities with infection prevention committees were about 1.78 times more likely to be knowledgeable
Table 2 Healthcare workers knowledge regarding infection prevention in healthcare facilities of West Arsi District, Southeast Ethiopia, April $2015(n=648)$

\begin{tabular}{|c|c|c|}
\hline Knowledge items & Number $^{a}$ & Percent \\
\hline $\begin{array}{l}\text { I have heard about infection prevention } \\
\text { principles }\end{array}$ & 575 & 88.7 \\
\hline $\begin{array}{l}\text { Gloves cannot provide complete protection } \\
\text { against transmission of infections }\end{array}$ & 385 & 59.4 \\
\hline $\begin{array}{l}\text { Washing hands with soap or use of an } \\
\text { alcohol based antiseptic decreases the } \\
\text { risk of transmission of healthcare acquired } \\
\text { infections }\end{array}$ & 429 & 66.2 \\
\hline $\begin{array}{l}\text { Use of an alcohol based antiseptic for } \\
\text { hand hygiene is as effective as soap and } \\
\text { water if hands are not visibly dirty }\end{array}$ & 422 & 65.1 \\
\hline $\begin{array}{l}\text { Gloves should be worn if blood or body } \\
\text { fluid exposure is anticipated }\end{array}$ & 403 & 62.2 \\
\hline $\begin{array}{l}\text { Hand washing is necessary before procedures } \\
\text { are performed }\end{array}$ & 300 & 46.3 \\
\hline $\begin{array}{l}\text { Tuberculosis (TB) is carried in airborne particles } \\
\text { that are generated from patients with active } \\
\text { pulmonary tuberculosis }\end{array}$ & 471 & 72.7 \\
\hline $\begin{array}{l}\text { There is no need to change gloves between } \\
\text { patients as long as there is no visible } \\
\text { contamination }\end{array}$ & 248 & 38.3 \\
\hline $\begin{array}{l}\text { Do you know how to prepare } 0.5 \% \text { chlorine } \\
\text { solution? }\end{array}$ & 365 & 56.3 \\
\hline $\begin{array}{l}\text { Safety box should be closed/sealed when } \\
\text { three quarters filled }\end{array}$ & 318 & 49.1 \\
\hline
\end{tabular}

"Healthcare workers "Yes" response

about infection prevention than their counterparts (AOR $=1.78,95 \%$ CI:1.01, 3.13). Those healthcare workers who have infection prevention guidelines in their working department were about 2.44 times more likely to be knowledgeable about infection prevention than those who don't $(\mathrm{AOR}=2.44,95 \% \mathrm{CI}: 1.45,4.12)$. Those healthcare workers who have ever taken training on infection prevention were about 5.02 times more likely to be knowledgeable about infection prevention than those who have not $(\mathrm{AOR}=5.02,95 \%$ CI:1.45,8.59) (Table 4). The study also identified a strong linear correlation between healthcare workers infection prevention knowledge score and the practice score (Pearson correlation coefficient $=$ $0.703, p<0.001)$.

\section{Factors associated with healthcare workers infection prevention practice}

In the bivariate analysis, sex, profession, service year, availability of water for hand washing in the healthcare worker's ward or department, the presence of an infection prevention committee, availability of infection prevention guidelines, and ever having taken taking training on infection prevention were factors which were significantly associated with healthcare workers' infection prevention practice. However, only profession, the presence 
Table 3 Infection prevention practice of healthcare workers in healthcare facilities of West Arsi District, Southeast Ethiopia, April $2015(n=648)$

\begin{tabular}{|c|c|c|c|}
\hline Practice items & Response & Number & Percent \\
\hline \multirow{2}{*}{$\begin{array}{l}\text { Do you apply antiseptic hand } \\
\text { rub to clean hands? }\end{array}$} & Yes & 403 & 62.2 \\
\hline & No & 245 & 37.8 \\
\hline \multirow{2}{*}{$\begin{array}{l}\text { Did you practice high-level } \\
\text { disinfection where sterilization } \\
\text { is not applicable? }\end{array}$} & Yes & 377 & 58.2 \\
\hline & No & 271 & 41.8 \\
\hline \multirow{2}{*}{$\begin{array}{l}\text { Do you use all Personal } \\
\text { Protective Equipment's (PPE) } \\
\text { to prevent the risk of acquiring } \\
\text { and/or transmitting infection? }\end{array}$} & Yes & 390 & 60.2 \\
\hline & No & 258 & 39.8 \\
\hline \multirow{2}{*}{$\begin{array}{l}\text { Did you mix dry and liquid } \\
\text { healthcare wastes? }\end{array}$} & Yes & 443 & 68.4 \\
\hline & No & 205 & 31.6 \\
\hline \multirow{2}{*}{$\begin{array}{l}\text { Do you incinerate or bury } \\
\text { used sharp materials? }\end{array}$} & Yes & 388 & 59.9 \\
\hline & No & 260 & 40.1 \\
\hline \multirow{4}{*}{$\begin{array}{l}\text { When do you change } \\
\text { disinfectant chlorine } \\
\text { solutions? }\end{array}$} & Every $24 \mathrm{~h}$ & 351 & 54.2 \\
\hline & Every two days & 174 & 26.8 \\
\hline & $\begin{array}{l}\text { Immediately when } \\
\text { it is soiled }\end{array}$ & 0 & 0 \\
\hline & I don't know & 123 & 19.0 \\
\hline \multirow{4}{*}{$\begin{array}{l}\text { For how long do you soak } \\
\text { reusable medical instruments } \\
\text { in chlorine } \\
\text { solution? }\end{array}$} & $10 \mathrm{~min}$ & 375 & 57.9 \\
\hline & $1 \mathrm{~h}$ & 203 & 31.3 \\
\hline & $24 \mathrm{~h}$ & 40 & 6.2 \\
\hline & $5 \mathrm{~min}$ & 30 & 4.6 \\
\hline \multirow{3}{*}{$\begin{array}{l}\text { How often do you use } \\
\text { glove (both hands)? }\end{array}$} & Always & 339 & 52.3 \\
\hline & Sometimes & 303 & 46.8 \\
\hline & Never & 6 & 0.9 \\
\hline \multirow{3}{*}{$\begin{array}{l}\text { Do you wear the necessary } \\
\text { personal protective equipment } \\
\text { (PPE) such as gloves, apron, } \\
\text { goggles and mask, if splashes } \\
\text { and spills of any body fluids } \\
\text { are likely? }\end{array}$} & Always & 253 & 39.0 \\
\hline & Sometimes & 381 & 58.8 \\
\hline & Never & 14 & 2.2 \\
\hline \multirow{4}{*}{$\begin{array}{l}\text { Where do you usually put } \\
\text { sharp disposal boxes? }\end{array}$} & In high traffic area & 153 & 23.6 \\
\hline & At corridor & 394 & 60.8 \\
\hline & Any where & 101 & 15.6 \\
\hline & Hand reach area & 0 & 0 \\
\hline
\end{tabular}

of infection prevention guidelines, and having ever taken ever taking training on infection prevention were found to be significantly associated in the multivariable logistic regression analysis.

Midwives were about $72 \%$ times less likely to use safe infection practices as compared to nurses $(\mathrm{AOR}=0.28$, $95 \%$ CI: $0.12,0.69$ ). Healthcare workers who have infection prevention guidelines available were 3.34 times more likely to practice safely infection prevention compared to those who do not have guideline for their practice (AOR $=3.34,95 \% \mathrm{CI}: 1.65,6.76)$. In addition, healthcare workers who have ever taken training on infection prevention were about 5.31 times more likely to practice safe infection prevention than those who have not received training $(\mathrm{AOR}=5.31,95 \% \mathrm{CI}$ : 2.42 , 11.63) (Table 5).

\section{Discussion}

Reducing the risk of HAIs and using infection prevention principles are in the control of healthcare workers; therefore, healthcare workers must have correct, up-to-date and appropriate scientific information and practice accordingly [48]. Without adequate infection prevention and patient safety practices both healthcare workers and patients are at risk of acquiring serious infections such as HIV, HBV, HCV, and Methicillin Resistant Staphylococcus aureus (MRSA) infection as well as other bacterial and viral infections [13, 49-51]. Recent studies also suggest that proper and consistent application of existing infection prevention and control practices can lead to up to a $70 \%$ reduction in certain HAIs [52, 53].

In this study, the proportion of healthcare workers who were knowledgeable about infection prevention was found to be $53.7 \%$. This finding indicated that a large percentage of respondents $(46.3 \%)$ in the healthcare facilities studied demonstrated inadequate knowledge about infection prevention, a finding in line with similar studies in Ethiopia [37, 39, 50] and in Africa [54]. On the other hand, the proportion of knowledgably participants is lower than studies in facilities in Bahir Dar city and Addis Ababa which reported $69 \%$ and $84.2 \%$ of healthcare workers had good infection control knowledge $[40,44]$. This discrepancy may be due to difference in study setting and study variables since the former study focused only the two components of infection prevention (hand hygiene and tuberculosis infection control) and includes only two university hospitals in Addis Ababa the later includes private healthcare facilities. Similarly, the result is inconsistent with that of Abdella et al. [41], who found that $77.3 \%$ of the respondents were knowledgeable on hand hygiene compliance, Gizaw et al. [43], who reported $63.9 \%$ of the respondents had good knowledge on tuberculosis infection control, and Shrestha et al. [55], who also found that more than half (54\%) of healthcare workers had good level of knowledge on tuberculosis infection control in Nepal. The variation in the percentage can be attributed to different methodological approaches and sample healthcare facility dissimilarity where in the previous studies they only assess a single infection prevention component like hand hygiene compliance and tuberculosis infection control while our study also included other infection prevention components such as medical instrument disinfection, personal protective equipment use, and healthcare waste handling. 
Table 4 Factors associated with healthcare workers infection prevention knowledge in healthcare facilities of West Arsi District, Southeast Ethiopia, April $2015(n=648)$

\begin{tabular}{|c|c|c|c|c|c|}
\hline \multirow[t]{2}{*}{ Variables } & \multirow[t]{2}{*}{ Category } & \multicolumn{2}{|c|}{ Infection prevention knowledge status } & \multirow{2}{*}{$\begin{array}{l}\text { Crude OR (95\% } \\
\text { Cl) }\end{array}$} & \multirow{2}{*}{$\begin{array}{l}\text { Adjusted OR } \\
(95 \% \mathrm{Cl})\end{array}$} \\
\hline & & $\begin{array}{l}\text { Knowledgeable } \\
(n=348)\end{array}$ & $\begin{array}{l}\text { Not-Knowledgeable } \\
(n=300)\end{array}$ & & \\
\hline \multirow[t]{2}{*}{ Sex } & Male & 182 & 264 & $0.15(0.09,0.22)^{*}$ & \\
\hline & Female & 166 & 36 & 1 & \\
\hline \multirow[t]{5}{*}{ Profession } & Nurse & 197 & 201 & 1 & 1 \\
\hline & Midwifery & 68 & 36 & $0.52(0.33,0.81)^{*}$ & $0.49(0.24,1.02)$ \\
\hline & Physician & 17 & 5 & $0.29(0.10,0.79)^{*}$ & $0.15(0.05,0.45)^{* *}$ \\
\hline & Health Officers & 29 & 22 & $0.74(0.41,1.34)$ & $0.54(0.21,1.38)$ \\
\hline & Laboratory technicians and other & 37 & 36 & $0.95(0.58,1.57)$ & $0.94(0.47,1.90)$ \\
\hline \multirow[t]{2}{*}{ Educational level } & Diploma & 201 & 193 & $0.75(0.55,1.04)$ & \\
\hline & First degree and above & 147 & 107 & 1 & \\
\hline \multirow[t]{3}{*}{ Year of service } & $<5$ years & 212 & 178 & 1 & 1 \\
\hline & $5-9$ years & 92 & 78 & $1.39(0.72,2.74)$ & $1.01(0.59,1.71)$ \\
\hline & $\geq 10$ years & 44 & 44 & $1.41(0.69,2.87)$ & $3.41(1.22,9.55)^{* *}$ \\
\hline \multirow{2}{*}{$\begin{array}{l}\text { Presence of infection } \\
\text { prevention committee }\end{array}$} & Yes & 281 & 149 & 1 & 1 \\
\hline & No & 67 & 151 & $2.35(0.17,0.33)^{*}$ & $1.78(1.01,3.13)^{* *}$ \\
\hline \multirow{2}{*}{$\begin{array}{l}\text { Availability of infection } \\
\text { prevention guidelines } \\
\text { in the working department }\end{array}$} & Yes & 231 & 79 & $5.52(3.93,7.76)^{*}$ & $2.44(1.45,4.12)^{* *}$ \\
\hline & No & 117 & 221 & 1 & 1 \\
\hline \multirow{2}{*}{$\begin{array}{l}\text { Ever taken infection } \\
\text { prevention training }\end{array}$} & Yes & 174 & 10 & $3.56(1.49,5.64)^{*}$ & $5.02(1.45,8.59)^{* *}$ \\
\hline & No & 174 & 290 & 1 & 1 \\
\hline
\end{tabular}

OR Odds Ratio ${ }^{*}(P<0.05)$ crude, ${ }^{* *}(p<0.05)$ adjusted, *Pharmacist, pharmacy technicians, anesthetist and environmental health officers

The implication of the finding suggested that healthcare workers in studied public healthcare facilities lack evidence-based knowledge and appropriate scientific information about infection prevention. The possible reason for lower finding in the current study might be due to lack of training about infection prevention, in this study only $28.4 \%$ of healthcare workers received infection prevention training.

As evidenced from the result of multivariable logistic regression analysis of this study and many related studies from Ethiopia, Italy, Nepal and Nigeria reported infection prevention knowledge of healthcare workers was positively associated with training [43, 50, 51, 55-57]. This could be due to the fact that updating the knowledge of the health workers about infection prevention principles could have changed the older understanding and could have resulted in good score on knowledge questions [50]. The finding highlights the necessity of infection prevention training in the improvement of healthcare workers knowledge.

This study showed that physicians are less knowledgeable about infection prevention than nurses. The result is consistent with Parmeggiani et al. [51] in Italy, who found that nurses were more likely to have greater knowledge than physicians on the use of standard precautions and hand hygiene to control HAIs. Inconsistent results were reported by
Alkubati et al. [58], who reported knowledge about prevention of central venous catheter-related infection was not significantly different between physicians and nurses in Egypt's Alexandria University hospital. Difference in knowledge level of health workers about infection prevention could be due to dissimilarity in training and awareness about infection prevention. Additionally, nurses are in the forefront of patients care in healthcare facilities, which could help them to have better knowledge.

This study also suggests that years of service of the study participants are significantly associated with knowledge about infection prevention. Healthcare workers who have served for ten and more years were about three times more likely to appear knowledgeable about infection prevention than those with less than five years service. This finding is in line with other related studies from Ethiopia [43, 44, 50], Africa [59], Europe [60], and Asia $[48,52]$, in which years of service year were positively associated with knowledge regarding infection prevention. The strong positive association from this study could be due to the fact that as the number of years of service increases, healthcare workers are repeatedly exposed to infection prevention principles and became more experienced and knowledgeable.

The presence of a positive linear correlation existed between healthcare workers total knowledge score and 
Table 5 Factors associated with healthcare workers infection prevention practice in selected healthcare facilities of West Arsi District, Southeast Ethiopia, April $2015(n=648)$

\begin{tabular}{|c|c|c|c|c|c|}
\hline \multirow[t]{2}{*}{ Variables } & \multirow[t]{2}{*}{ Category } & \multicolumn{2}{|c|}{ Infection prevention practice status } & \multirow{2}{*}{$\begin{array}{l}\text { Crude OR } \\
(95 \% \mathrm{Cl})\end{array}$} & \multirow{2}{*}{$\begin{array}{l}\text { Adjusted OR } \\
(95 \% \mathrm{Cl})\end{array}$} \\
\hline & & Safe $(n=235)$ & Unsafe (413) & & \\
\hline \multirow[t]{2}{*}{ Sex } & Male & 92 & 354 & $0.11(0.07,0.15)^{*}$ & \\
\hline & Female & 143 & 59 & 1 & \\
\hline \multirow[t]{5}{*}{ Profession } & Nurse & 134 & 264 & 1 & 1 \\
\hline & Midwifery & 44 & 60 & $0.37(0.24,0.58)^{*}$ & $0.28(0.12,0.69)^{* *}$ \\
\hline & Physician & 19 & 3 & $3.22(0.94,11.06)$ & $2.99(0.25,36.08)$ \\
\hline & Health officers & 17 & 34 & $1.02(0.55,1.88)$ & $0.44(0.15,1.34)$ \\
\hline & $\begin{array}{l}\text { Laboratory } \\
\text { technicians } \\
\text { and other }\end{array}$ & 21 & 52 & $1.26(0.73,2.17)$ & $2.83(0.83,9.60)$ \\
\hline \multirow[t]{2}{*}{ Educational level } & Diploma & 143 & 251 & $1.00(0.72,1.39)$ & \\
\hline & $\begin{array}{l}\text { First degree } \\
\text { and above }\end{array}$ & 92 & 162 & 1 & \\
\hline \multirow[t]{4}{*}{ Year of service } & $<5$ years & 147 & 243 & 1 & 1 \\
\hline & $5-9$ years & 61 & 109 & $1.08(0.74,1.57)$ & $0.57(0.18,1.83)$ \\
\hline & $10-14$ years & 11 & 37 & $2.05(1.01,4.11)^{*}$ & $0.49(0.15,1.67)$ \\
\hline & $\geq 15$ years & 16 & 24 & $0.91(0.47,1.76)$ & $3.17(0.47,21.24)$ \\
\hline \multirow{2}{*}{$\begin{array}{l}\text { Availability of water in } \\
\text { working department }\end{array}$} & Yes & 203 & 318 & 1 & 1 \\
\hline & No & 32 & 95 & $1.89(1.22,2.94)^{*}$ & $0.35(0.06,1.96)$ \\
\hline \multirow{2}{*}{$\begin{array}{l}\text { Presence of infection } \\
\text { prevention committee }\end{array}$} & Yes & 199 & 231 & 1 & 1 \\
\hline & No & 36 & 182 & $4.36(2.91,6.53)^{*}$ & $1.204(0.55,2.62)$ \\
\hline \multirow{2}{*}{$\begin{array}{l}\text { Availability of infection } \\
\text { prevention guidelines } \\
\text { in the working department }\end{array}$} & Yes & 167 & 143 & $4.64(3.28,6.56)^{*}$ & $3.34(1.65,6.76)^{* *}$ \\
\hline & No & 68 & 270 & 1 & 1 \\
\hline \multirow{2}{*}{$\begin{array}{l}\text { Ever taken infection } \\
\text { prevention }\end{array}$} & Yes & 126 & 58 & $7.08(4.85,10.32) *$ & $5.31(2.42,11.63) * *$ \\
\hline & No & 109 & 355 & 1 & 1 \\
\hline
\end{tabular}

OR Odds Ratio $*(P<0.05)$ crude, ${ }^{* *}(p<0.05)$ adjusted, Pharmacist, pharmacy technicians, anesthetist and environmental health officers

practice (Pearson correlation coefficient $=0.703, p<0.001$ ) is also in agreement with studies conducted in Ethiopia and elsewhere $[43,52]$. As a result with improved knowledge, practice can be also improved.

In this study, the proportion of healthcare workers who appear to be practicing safe infection prevention practice was $36.3 \%$. This result is much lower than with many similar studies in Ethiopia [37, 39, 42-44, 50]. This may be explained by the fact that the vast majority healthcare workers in the study area (71.6\%) had not received infection prevention training and had inadequate infection prevention knowledge. As well (60.2\%) of these workers had less than five year's work experience. Our study may have indicated a gap in training which could result in poor infection prevention practice among healthcare workers.

The current finding is lower than a study done in an Egyptian hospital where $57.1 \%$ of the health workers were found to practice satisfactory infection prevention activities [61]. This could be due to differences in study setting, study variables, a difference in the definition of satisfactory practice and other methodological concerns. Difference in knowledge of the healthcare workers concerning infection prevention could be another factor for this inconsistency. However, the findings here are better than those findings from studies done in Iran where only $32.1 \%$ of healthcare workers reported moderately-good compliance in hand hygiene [52]. Similarly, the finding is better than reported by Abdella et al., from Ethiopia which reported healthcare providers hand hygiene compliance of $16.5 \%$ in Gondar University Hospital [41].

The low percentages of healthcare workers adherence to infection prevention principles in the present study may be explained by factors suggested by the questions posed to workers. On one hand, poor baseline knowledge of infection prevention principles may contribute importantly. On the other hand, other factors such as lack of supportive supervision from an infection prevention committee, and other organizational supports may be lacking.

The present study also found out significant differences in the practice of infection prevention among 
healthcare workers who had infection prevention training and have infection prevention guideline in their working department. The odds of safe practice were likely to be three and five times higher in healthcare workers who had infection prevention guidelines available and trained in infection prevention respectively. This finding is in agreement with other similar studies in Ethiopia [37, 41-43, 50, 57] and elsewhere [51].

Another factor which was significantly associated with safe infection prevention practice is profession. This study found out differences in the reported practices of infection prevention among different healthcare professionals, such as the odds of safe practice among midwifes likely to be reduced by $72 \%$ compared to nurses. Other research by Biniyam et al. [37] has reported dissimilar infection prevention practices between physicians and laboratory technicians in Ethiopia, and between nurses and physicians by Parmeggiani et al. [51] in Italy. This could be due to difference in training and operational definition of the practice from study to study. Variation in job description of different health professionals may be another factor for this discrepancy.

Year of service was not found to be statistically significant on multivariable analysis in this study. However, in the bivariate analysis the odds ratio suggests that healthcare workers who have higher ten and above service year were about two times more likely to had safe practice when compared with those who had less than five. In support of this, Hosseinialhashemi et al. [52] from Iran, reported a correlation between hand hygiene practice and work experience $(p<0.05)$.

The current study also detected a potential high prevalence of occupational exposure to needle stick injury and blood and body fluid splashes among healthcare workers in the study area, which is similar to other related studies in Ethiopia [37, 38]. The problem highlights the need to improve safe infection practice across healthcare facilities.

This study has several limitations; due to the crosssectional nature of this study design temporal relationships cannot be established between the explanatory and outcome variables of infection prevention knowledge and practice. Despite, the high response rate in this study, social desirability bias and recall bias are potential limitations of these self-reported results. Healthcare workers might not give true and genuine responses on the self-administered questionnaire, preferring to provide more socially acceptable responses than their actual day to day practice. Lack of standardized questionnaires with acceptable reliability and validity for assessing infection prevention knowledge and practice in Ethiopia was another limitation of the study that limits our findings. To overcome this problem we included items that are acceptable face-validly and reliability, used by other authors in order to aid comparison. One additional limitation of this study is that the generalization of findings limited to public healthcare facilities.

\section{Conclusion}

The present study revealed that a significant proportion of healthcare workers were not knowledgeable about infection prevention. The overall level of safe infection prevention practice among healthcare workers is considered to be very low. The current study also detected that there was a high prevalence of occupational needle stick injury and blood and body fluid splashes among healthcare workers. Factors such as the presence of infection prevention guidelines in the work place and training were independent predictors of safe infection prevention practice and better knowledge. Providing on job continuous educational training on infection prevention is essential as well as ensuring the availability of infection prevention guidelines in working department should be effective and important interventions to improve healthcare workers infection prevention practice and knowledge. In the future researchers should consider stronger observational study designs to validate the self-reported practice of healthcare workers and to determine actual practices, as well as the actual prevalence of HAIs as result of poor infection prevention practice.

\section{Abbreviations}

AOR: Adjusted odds ratio; CDC: Centers for disease control and prevention; Cl: Confidence interval; COR: Crude odds ratio; HAls: Healthcare associated infections; HBV: Hepatitis B virus; HCV: Hepatitis C virus; HIV: Human immunodeficiency virus; IRB: Institutional review board; PPE: Personal protective equipments; SPSS: Statistical package for social sciences and; TB: Tuberculosis; WHO: World Health Organization

\section{Acknowledgements}

We are grateful to study participants, facilitators and supervisors for their commitment to participation in this study. We also deeply indebted to thank Dodola and Kuyara Hospital, Health office in West Arsi District, Shashamane Town, Asasa Woreda, and Health centers in Gobe, Kofele, Arsi Nagele, Shashamane, and Dodola for allowing access to their facilities and for their cooperation.

\section{Availability of data and materials}

Data is available upon request from the correspondence authors.

\section{Authors' contributions}

BS contributed to the data analysis and performs interpretation, drafted and writing the manuscript. GM conceived of the study, design of the study and tool development, coordinated data collection, and performed statistical analysis. BW participated in the design of the study, tool development, contributed to the data analysis and interpretation. All authors read and approved the final manuscript.

\section{Ethics approval and consent to participate}

Ethical clearance was obtained from Institutional Review Board (IRB) of Addis Ababa University College of Health Science and a formal letter of permission was obtained from the West Arsi Health Office and from selected health centers and hospitals to access healthcare facilities. Written informed consent was obtained from each individual respondent. Confidentiality of information gathered was assured during and after data collection by facilitators and investigators by using code numbers rather than personal identifiers. 


\section{Consent for publication}

Not applicable.

\section{Competing interests}

The authors declare that they have no competing interests.

\section{Publisher's Note}

Springer Nature remains neutral with regard to jurisdictional claims in published maps and institutional affiliations.

\section{Author details}

'Department of Public Health, School of Health Science, Madda Walabu University Goba Referral Hospital, Bale-Goba, Ethiopia. ${ }^{2}$ Department of Nursing, School of Health Science, Madda Walabu University Goba Referral Hospital, Bale-Goba, Ethiopia. ${ }^{3}$ Department of Nursing and Midwifery, School of Health Science, Addis Ababa University, Addis Ababa, Ethiopia.

Received: 16 May 2018 Accepted: 25 September 2018

Published online: 12 November 2018

\section{References}

1. Allegranzi B, Bagheri S, Combescure C, Graafmans W, Attar H, Donaldson L, Pittet D. Burden of endemic health care-associated infection in developing countries: systematic review and meta-analysis. Lancet. 2011;377:288-41.

2. Allegranzi B, Storr J, Dziekan G, Leotsakos A, Donaldson L, Pittet D. The first global patient safety challenge "clean care is safer care": from launch to current progress and achievements. J Hosp Infect. 2007;65(Suppl 2):115-23.

3. $\mathrm{CDC} / \mathrm{NHSN}$. CDC/NHSN surveillance definition of health care-associated infection and criteria for specific types of infections in the acute care setting. Am J Infect Control. 2008;36:309-32.

4. Rosenthal V, Al-Abdely H, El-Kholy A, AlKhawaja S, Leblebicioglu H, Mehta Y, et al. International nosocomial infection control consortium report, data summary of 50 countries for 2010-2015: device-associated module. Am J Infect Control. 2016:44:1495-504.

5. Uwaezuoke SN, Obu HA. Nosocomial infections in neonatal intensive care units: cost-effective control strategies in resource-limited countries. Niger J Paediatrics. 2013;40(2):125-32.

6. Kennedy E, Greene M, Saint S. Estimating hospital costs of catheterassociated urinary tract infection. J Hosp Med. 2013;8(9):519-22.

7. Green N, Johnson A, Henderson K, Muller-Pebody B, Thelwall S, Robotham J, et al. Quantifying the burden of hospital-acquired bloodstream infection in children in England by estimating excess length of hospital stay and mortality using a multistate analysis of linked, routinely collected data. J Pediatric Infect Dis Soc. 2015;4(4):305-12.

8. Plowman R, Graves N, Griffin M, Roberts J, Swan A, Cookson B, et al. The rate and cost of hospital acquired infections occurring in patient admitted to selected specialists of a district general hospital in England and the various burden imposed. J Hosp Infect. 2001;4(7):198-09.

9. WHO. Health care-associated infections FACT SHEET. 2016. http://www. who.int/gpsc/country_work/gpsc_ccisc_fact_sheet_en.pdf. Accessed 20 May 2018.

10. Healthcare-Associated Infection Working Group of the Joint Public Policy Committee. Essentials of public reporting of healthcare- associated infections: a tool. Centers for Disease Control and Prevention (CDC). Accessed March. 2018:12 Available at: http://www.cste2.org/webpdfs/ 06107498EssentialsToolKit.pdf.

11. Suetens C, Hopkins S, Kolman J, Diaz Högberg L, European Centre for Disease Prevention and Control. Point prevalence survey of healthcare associated infections and antimicrobial use in European acute care hospitals. Sweden: ECDC; 2013.

12. Shelley S, Walter H, Robyn K, Christine B, Bonnie B, et al. Prevalence of healthcare-associated infections in acute care hospitals in Jacksonville, Florida. Infect Control Hosp Epidemiol. 2012;33(3):283-91.

13. Federal Ministry of Health of Ethiopia. Infection prevention and patient safety reference manual for service providers and managers in healthcare facilities of Ethiopia. $2^{\text {nd }}$ ed. Addis Ababa, Ethiopia. 2012.

14. Tietjen L, Bossemeyer D, Mclntosh N. Infection prevention: guidelines for healthcare facilities with limited resources. Maryland: JHPIEGO; 2003.

15. Raka L. Prevention and control of hospital-related infections in low and middle income countries. Open Infect Dis J. 2010;4:125-31.
16. Nejad S, Allegranzi B, Syed S, Ellis B, Pittet D. Healthcare-associated infection in Africa: a systematic review. Bull World Health Organ. 2011;89:757-65.

17. Rothe C, Schlaich C, Thompson S. Healthcare-associated infections in subSaharan Africa. J Hosp Infect. 2013;85(4):257-67.

18. Endalafer N, Gebereselassie S, Kotiso B. Nosocomial bacterial infections in a tertiary hospital in Ethiopia. J Infect Prev. 2011;12(1):38-43.

19. Walelegn W, Abera K, Feleke M. Point prevalence of hospital-acquired infections in two teaching hospitals of Amhara region in Ethiopia. Drug Healthc Patient Saf. 2016:8:71-6.

20. Amenu D, Belachew T, Araya F. Surgical site infection rate and risk factors among obstetric cases of Jimma University specialized hospital, Southwest Ethiopia. Ethiop J Health Sci. 2011;21(2):91-100.

21. Nigatu E, Solomon G, Berhanu K. Nosocomial bacterial infections in a tertiary hospital in Ethiopia. J Infect Prev. 2011;12(1):38-43.

22. Kuzdan C, Soysal A, Çulha G, Altınkanat G, Söyletir G, Bakır M. Three-year study of health care-associated infections in a Turkish pediatric ward. J Infect Dev Ctries. 2014;8:1415-20.

23. Hacimustafaoglu M, Celebi S, Tuncer E, Ozkaya G, Cakir D, Bozdemir SE. Nosocomial infection incidence in pediatric clinic and pediatric intensive care unit/Cocuk klinigi ve cocuk yogun bakim unitesi hastane enfeksiyonlari sikligi. J Pediatric Infect. 2009;1:112-8.

24. Samuel S, Kayode O, Musa O, et al. Nosocomial infections and the challenges of control in developing countries. Afr J Clin Exp Microbiol. 2010;11(2):102-10.

25. National Infection Prevention Guidelines for Healthcare Facilities in Ethiopia. Federal Ministry of Health Ethiopia. Addis Ababa Ethiopia: Disease Prevention and Control Department; 2005.

26. Alice W, Simon M, Elijah N, Ngalo O. Healthcare workers adherence to infection prevention practices and control measures: a case of a level four district hospital in Kenya. Am J Nurs Sci. 2015;4(2):39-44.

27. WHO. Health care-associated infections FACT SHEET. Patient safety a world alliance for safer health care. 2017. www.who.int/gpsc/country_work/gpsc_ ccisc_fact_sheet_en.pdf Accessed 25 Nov 2017.

28. Pittet $\mathrm{D}$. Role of hand hygiene in healthcare-associated infection prevention J Hosp Infect. 2009;73:305-15.

29. Sickbert-Bennett E, DiBiase L, Willis M, Wolak S, Weber D, Rutala W. Reduction of healthcare-associated infections by exceeding high compliance with hand hygiene practices. Emerg Infect Dis. 2016;22(9):1628-30.

30. WHO. Health care without avoidable infections: the critical role of infection prevention and control. World Health Organization (WHO). 2016. http:// apps.who.int/iris/bitstream/handle/10665/246235/WHO-HIS-SDS-2016.10eng.pdf? sequence=1\&isAllowed=y. Accessed 25 Nov 2017.

31. Creedon SA. Healthcare workers hand decontamination, practices with recommendation guidelines. J Adv Nurs. 2005;51(3):208-16.

32. Scott RD. The direct medical costs of healthcare-associated infections in US hospitals and the benefits of prevention. Atlanta: Centers for Disease Control and Prevention; 2009.

33. Alp E, Leblebicioglu H, Doganay M, Voss A. Infection control practice in countries with limited resources. Ann Clin Microbiol Antimicrob. 2011;10:36.

34. Indah K, Trevor D, Sharon K, Andrew J, Yati S. Reducing hospital-acquired infections and improving the rational use of antibiotics in a developing country: an effectiveness study. Arch Dis Child. 2015;100:454-9.

35. Allegranzi B, Pittet D. Healthcare-associated infection in developing countries: simple solutions to meet complex challenges. Infect Control Hosp Epidemiol. 2007;28(12):1323-7.

36. Ogoina D, Pondei K, Adetunji B, Chima G, Isichei C, Gidado S. Knowledge, attitude and practice of standard precautions of infection control by hospital worker in two tertiary hospitals in Nigeria. J Infect Prev. 2015;16(1):16-22.

37. Biniyam S, Azeb G, Desta H, Tadesse G. Infection prevention practices and associated factors among healthcare workers in governmental healthcare facilities in Addis Ababa, Ethiopia. Ethiop J Health Sci. 2018;28(2):177-86.

38. Reda A, Fisseha S, Mengistie B, Vandeweerd J-M. Standard precautions: occupational exposure and behavior of health care workers in Ethiopia. PLoS One. 2010;5(12):e14420.

39. Geberemariyam BS. Instrument processing knowledge and practice amongst healthcare workers in Addis Ababa, Ethiopia. Int J Infect Control. 2018;14:2.

40. Tenna A, Stenehjem E, Margoles L, Kacha E, Blumberg H, Kempker R. Infection control knowledge, attitudes, and practices among healthcare workers in Addis Ababa, Ethiopia. Infect Control Hosp Epidemiol. 2013; 34(12):1289-6. 
41. Abdella N, Tefera M, Eredie A, Landers T, Malefia Y, Alene K. Hand hygiene compliance and associated factors among health care providers in Gondar University hospital, Gondar, North West Ethiopia. BMC Public Health. 2014;14:96.

42. Gebresilassie A, Kumei A, Yemane D. Standard precautions practice among health care workers in public health facilities of Mekelle special zone, northern Ethiopia. J Community Med Health Educ. 2014;4(3):286.

43. Gizaw G, Alemu Z, Kibret K. Assessment of knowledge and practice of health workers towards tuberculosis infection control and associated factors in public health facilities of Addis Ababa, Ethiopia: a cross-sectional study. Arch Public Health. 2015;73:15.

44. Gulilat K, Tiruneh G. Assessment of knowledge, attitude and practice of health care workers on infection prevention in health institution Bahir Dar city administration. Sci J Public Health. 2014;2(5):384-3.

45. Sambo LG, Chatora RR, Goosen ES. Tools for assessing the operationality of district health systems. Brazzaville: World Health Organization, Regional Office for Africa; 2003.

46. Vittinghoff E, Glidden DV, Shiboski SC, McCulloch CE. Logistic regression. InRegression methods in biostatistics. Boston: Springer; 2012.(pp. 139-202).

47. Hosmer Jr DW, Lemeshow S, Sturdivant RX. Applied logistic regression. 3rd edn John New York: Wiley;2013.

48. Kalantarzadeh M, Mohammadnejad E, Ehsani SR, Tamizi Z. Knowledge and practice of nurses about the control and prevention of nosocomial infections in emergency departments. Arch Clin Infect Dis. 2014;9:4.

49. Kahsay A, Mihret A, Abebe T, Andualem T. Isolation and antimicrobial susceptibility pattern of Staphylococcus aureus in patients with surgical site infection at Debre Markos referral hospital, Amhara Region, Ethiopia. Arch Public Health. 2014;72:16.

50. Teshager FA, Engeda EH, Worku WZ. Knowledge, practice, and associated factors towards prevention of surgical site infection among nurses working in Amhara regional state referral hospitals, Northwest Ethiopia. Surg Res Pract. 2015;2015. https://doi.org/10.1155/2015/736175.

51. Parmeggiani C, Abbate R, Marinelli P, Angelillo IF. Healthcare workers and health care-associated infections: knowledge, attitudes, and behavior in emergency departments in Italy. BMC Infect Dis. 2010;10:35.

52. Hosseinialhashemi M, Kermani F, Palenik C, Pourasghari H, Askarian M. Knowledge, attitudes, and practices of health care personnel concerning hand hygiene in Shiraz University of Medical Sciences hospitals, 2013-2014. Am J Infect Control. 2015:43(9):1009-11.

53. Dick AW, Pogorzelska-Maziarz M, Larson EL. A decade of investment in infection prevention: a cost-effectiveness analysis. Am J Infect Control. 2015;43:4-9.

54. Eskander HG, Morsy WY, Elfeky HA. Intensive care nurses' knowledge \& practices regarding infection control standard precautions at a selected Egyptian cancer hospital. J Educ Pract. 2013;4:19.

55. Shrestha A, Bhattarai D, Thapa B, Basel P, Wagle R. Health care workers' knowledge, attitudes and practices on tuberculosis infection control, Nepal. BMC Infect Dis. 2017;17:724.

56. Brisibe S, Ordinioha B, Gbeneolol P. Knowledge, attitude, and infection control practices of two tertiary hospitals in Port-Harcourt, Nigeria. Niger J Clin Pract. 2014;17(6):691-5.

57. Temesgen C, Demissie M. Knowledge and practice of tuberculosis infection control among health professionals in Northwest Ethiopia; 2011. BMC Health Serv Res. 2014;14:593.

58. Alkubati S, Ahmed N, Mohamed O, Fayed A, Asfour H. Health care workers' knowledge and practices regarding the prevention of central venous catheter-related infection. Am J Infect Control. 2015;43(1):26-30.

59. Famakinwa TT, Bello BG, Oyeniran YA, Okhiah O, Nwadike RN. Knowledge and practice of post-operative wound infection prevention among nurses in the surgical unit of a teaching hospital in Nigeria. Int J Basic Appl Innov Res. 2014;3(1):23-8.

60. Fashafsheh I, Ayed A, Eqtait F, Harazneh L. Knowledge and practice of nursing staff towards infection control measures in the Palestinian hospitals. J Educ Pract. 2015;6(4):79-90.

61. El-Enein N, El Mahdy H. Standard precautions: a KAP study among nurses in the dialysis unit in a university hospital in Alexandria, Egypt. J Egypt Public Health Assoc. 2011;86(12):3-10.

\section{Ready to submit your research? Choose BMC and benefit from:}

- fast, convenient online submission

- thorough peer review by experienced researchers in your field

- rapid publication on acceptance

- support for research data, including large and complex data types

- gold Open Access which fosters wider collaboration and increased citations

- maximum visibility for your research: over $100 \mathrm{M}$ website views per year

At BMC, research is always in progress.

Learn more biomedcentral.com/submissions 